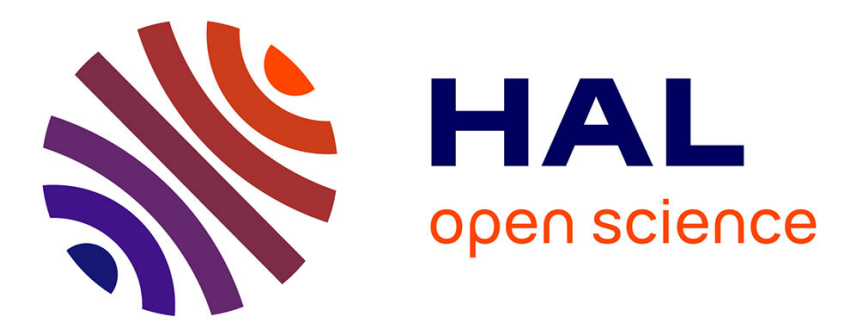

\title{
Inter-Firm Trust in Buyer-Supplier Relations: Are Knowledge Spillovers and Geographical Proximity Relevant?
}

Werner Bönte

\section{- To cite this version:}

Werner Bönte. Inter-Firm Trust in Buyer-Supplier Relations: Are Knowledge Spillovers and Geographical Proximity Relevant?. Journal of Economic Behavior and Organization, 2008, 67 (3-4), pp.855. 10.1016/j.jebo.2006.12.004 . hal-00614673

\section{HAL Id: hal-00614673 \\ https://hal.science/hal-00614673}

Submitted on 15 Aug 2011

HAL is a multi-disciplinary open access archive for the deposit and dissemination of scientific research documents, whether they are published or not. The documents may come from teaching and research institutions in France or abroad, or from public or private research centers.
L'archive ouverte pluridisciplinaire $\mathbf{H A L}$, est destinée au dépôt et à la diffusion de documents scientifiques de niveau recherche, publiés ou non, émanant des établissements d'enseignement et de recherche français ou étrangers, des laboratoires publics ou privés. 


\section{Accepted Manuscript}

Title: Inter-Firm Trust in Buyer-Supplier Relations: Are Knowledge Spillovers and Geographical Proximity Relevant?

Author: Werner Bönte

PII: S0167-2681(07)00166-7

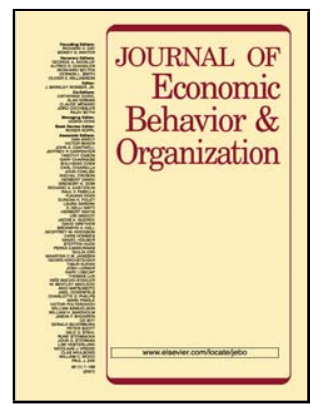

DOI: doi:10.1016/j.jebo.2006.12.004

Reference: JEBO 2138

To appear in: Journal of Economic Behavior \& Organization

Received date: 23-12-2004

Accepted date: $16-12-2006$

Please cite this article as: Bönte, W., Inter-Firm Trust in Buyer-Supplier Relations: Are Knowledge Spillovers and Geographical Proximity Relevant?, Journal of Economic Behavior and Organization (2007), doi:10.1016/j.jebo.2006.12.004

This is a PDF file of an unedited manuscript that has been accepted for publication. As a service to our customers we are providing this early version of the manuscript. The manuscript will undergo copyediting, typesetting, and review of the resulting proof before it is published in its final form. Please note that during the production process errors may be discovered which could affect the content, and all legal disclaimers that apply to the journal pertain. 


\begin{abstract}
This paper empirically examines the impact of knowledge spillovers and geographical proximity on inter-firm trust in buyer-supplier relations. In particular, the effects of incoming knowledge spillovers from vertically-related firms and firms' appropriability problems are analyzed. The results suggest that there is a positive relationship between incoming knowledge spillovers from business partners and the level of inter-firm trust. Firms' appropriability problems, however, lead to a decrease in inter-firm trust. Firms that cannot protect their technical knowledge have a greater perception of customer (supplier) opportunism. Furthermore, estimation results indicate that inter-firm trust between geographically close partners exceeds inter-firm trust between distant partners.
\end{abstract}

JEL classification: D21; D23; L14; L20

Keywords: Trust; Opportunism; Buyer-Supplier Relations; Knowledge Spillovers; Geographical Proximity 


\title{
Inter-Firm Trust in Buyer-Supplier Relations: Are Knowledge Spillovers and Geographical Proximity Relevant?
}

\author{
Werner Bönte \\ Max Planck Institute of Economics \\ Entrepreneurship, Growth and Public Policy Group \\ Kahlaische Straße 10 \\ D-07745 Jena \\ E-mail: boente@econ.mpg.de \\ Telephone: ++49-3641-686720 \\ Fax: $++49-3641-686710$
}

August 15, 2007 
"Trust is the glue that holds everything together, the bond that creates healthy communities and successful businesses." Klaus Schwab and Thierry Malleret (2003)

\section{Introduction}

At first glance, the optimistic view expressed in the quotation seems to exaggerate the relevance of trust for economic development. However, recent empirical studies give support to the hypothesis that trust is important. At the macroeconomic level, Knack and Keefer (1997), La Porta et al. (1997) and Zak and Knack (2001) have found that an increase in country-level trust leads to an increase in economic growth. At the microeconomic level, the existing empirical literature suggests that trust in buyer-supplier relations fosters firm performance (Zaheer et al. 1998, Sako 2000, Dyer and Chu 2003). In particular, a higher level of trust has a positive impact on just-intime delivery and continuous improvement and learning (Sako 2000), and it may reduce transaction costs of vertically-related firms substantially (Dyer and Chu 2003). ${ }^{1}$

A natural question arising from this is what the sources of trust are. It is argued in the literature that one important determinant of trust is the exchange of information between individuals (Fisman and Khanna 1999). Sako (1998) has postulated that inter-firm trust requires multiple channels of information flows (communication) between firms and the diffusion of this information within firms. This paper investigates empirically the relevance of knowledge spillovers and geographical proximity for inter-firm trust in buyersupplier relations for a sample of aeronautical firms in Germany.

\footnotetext{
${ }^{1}$ In these studies supplier-automaker relationships in the US, Japan and Korea are investigated.
} 
Thus far, the empirical literature on the relevance of information flows for inter-firm trust is scarce. Sako and Helper (1998) and Sako (1998) have investigated the impact of information flows on suppliers' trust in their customers for the automotive industry in the USA, Japan and Europe. Their results suggest that the provision of information by customers concerning their final consumers, their financial situation, and the usage of a supplier's product in their production process increases a supplier's trust. Dyer and Chu (2000), who have investigated the customer trust of US, Japanese, and Korean automotive suppliers, found that a supplier's trust in automakers increases if the latter are providing regular technical assistance to the supplier in order to help the former to improve product quality, to reduce manufacturing costs, or to improve inventory management.

In contrast to these empirical studies that focus on the effects of voluntary knowledge sharing, this study pays special attention to the effects of involuntary leakage of knowledge. In particular, it is examined whether a firms' ability to appropriate the returns from its proprietary innovations influences a firm's trust in vertically related firms. Moreover, the effects of incoming knowledge spillovers from vertically related firms, which may be generated by voluntary or involuntary knowledge sharing, are examined.

Furthermore, existing empirical studies on the determinants of inter-firm trust provide some indirect evidence for the relevance of geographical proximity for the emergence of trust. Dyer and Chu (2000), for instance, state that there is more face-to-face communication between suppliers and automakers in Japan than in U.S. or Korea, which may positively affect trust. They argue that this may be facilitated by geographical proximity of suppliers and automakers in Japan. ${ }^{2}$ Lane and Bachmann (1996) have investigated supplier relations in Britain and Germany and conclude that geographical

\footnotetext{
${ }^{2}$ In their sample the average distance between supplier and automaker plants is the lowest in Japan and the highest in the United States.
} 
proximity of firms fosters the creation of inter-firm trust. ${ }^{3}$ However, these are qualitative statements, not statistical tests for the relevance of geography.

In this study the relevance of geographical proximity for inter-firm trust is explored empirically. Since the dataset used in this study contains information about a firm's trust in proximate and distant trading partners, this allows for investigating the relevance of geographical proximity by using econometric estimation techniques. Panel data estimation techniques are employed that control for unobserved firm-specific effects that have not been taken into account in previous studies based on cross-section regressions.

The sample used in this study comprises 179 firms that have in common an aeronautical affinity: for example firms are from the aerospace industry, suppliers of aeronautic firms, or R\&D cooperation partners. The majority of these firms are innovative firms that are engaged in R\&D and have introduced at least one product innovation in the two years preceding the survey. This sample of firms is appropriate for an investigation of the relevance of appropriability conditions and incoming spillovers for inter-firm trust because it is likely that voluntary and involuntary sharing of technical knowledge is important, especially for innovative firms.

The empirical results of this study suggest that incoming knowledge spillovers, appropriability problems, and geographic proximity are indeed relevant for inter-firm trust. The inflow of knowledge from trading partners and the spatial proximity of trading partners have a positive impact on a firm's trust in trading partners. In contrast, firms with appropriability problems exhibit a lower level of inter-firm trust, all other things being equal. Furthermore, estimation results indicate that trust in customers exceeds trust in suppliers.

The rest of the paper is arranged as follows. In the next section, the economic approach to trust is discussed and hypotheses about the determinants of inter-firm trust are derived. Section 3 contains a detailed description of the

\footnotetext{
${ }^{3}$ Their study is based on 44 lengthy semi-structured interviews.
} 
data and descriptive statistics. The econometric specification and estimation results are presented in Section 4. Section 5 summarizes the findings.

\section{Conceptual Framework}

Sako (1998, p. 26) defines trust "as a mutual expectation that partners will not exploit the vulnerabilities created by cooperation". 4 Since trust has its basis in individuals, it is not appropriate to say that organizations trust each other. It is possible, however, that employees of one firm may share a trust orientation toward employees of another firm. Such a shared orientation may diffuse within an organization through various forms of communication, such as word-of-mouth communication (for example lunch conversations). According to Zaheer et al. (1998, p. 143) "interorganizational trust describes the extent to which organizational members have a collectively-held trust orientation toward the partner firm, which is quite different from saying that organizations trust each other" ${ }^{5}$ However, what does inter-firm trust exactly mean?

Recently, James (2002) has argued that one should distinguish between 'trust as prudence' and 'trust as hope'. The former means that Firm $A$ will trust Firm $B$ if Firm $A$ knows that Firm $B$ has no incentive to exploit Firm $A$ 's trust. He calls this 'trust as prudence' since it is 'prudent' for an agent to trust another agent, if the latter has no incentive to exploit the trust. However, as pointed out by James (p. 293), this leads to the following trust paradox: “..., if I know that my partner does not have an incentive to exploit my trust, does it make sense for me to say that I trust her?" In contrast, "trust as hope' means that a firm decides to trust another firm hoping that trust

\footnotetext{
${ }^{4}$ Of course, not every cooperation between firms necessarily creates vulnerabilities; for example sufficiently complete contracts may discipline firms.

${ }^{5}$ The empirical results reported by Zaheer et al. suggest that interpersonal and interorganizational trust are related but distinct constructs.
} 
will not be exploited, although the other firm may have an incentive to do so (James, p. 303). To understand the difference between trust as prudence and trust as hope, it is helpful to refer to Craswell's (1993) distinction of trust as behavior (explanandum) vs. trust as cause of behavior (explanans). Trust as behavior is just a simple label assigned to a certain strategy. In contrast, trust as cause of behavior means that trust determines behavior.

This distinction can be clarified by Figure 1, which reports the pay-offs of a simple game (Prisoners' dilemma). A supplier and a customer have to decide whether or not to trust each other. If the supplier trusts the customer and the customer also trusts the supplier, both firms receive a amount of money $(\mathrm{a}>0)$. If the the supplier chooses the 'Trust' strategy and the customer the 'No Trust' strategy, the supplier has a negative pay-off $(d>$ 0 ) and the customer gets an additional amount of money $(c>0)$, and vice versa. If both choose the 'No Trust' strategy, their payoffs are zero.

\section{Insert Figure 1}

Suppose that this game is infinitely repeated. If both firms make use of standard trigger strategies and the discount factor is sufficiently high, they will choose the 'Trust' strategy in each period since they are better off by choosing this strategy than by choosing the 'No Trust' strategy. ${ }^{6}$ This behavior can be labeled as trust. In contrast, the Nash equilibrium of the oneshot version of the game is the 'No Trust' strategy. If one firm still chooses the 'Trust' strategy in the one shot version, this behavior may be caused by the firm's 'trust' in the other firm. Thus 'trust as prudence' corresponds to 'trust as behavior' and 'trust as hope' corresponds to 'trust as cause of behavior'.

\footnotetext{
${ }^{6}$ For instance, a firm that deviates from choosing the 'Trust' strategy can be punished by the other firm since the latter can then play the static Nash equilibrium ('No Trust') in all following periods.
} 
Unfortunately, 'trust as hope' and 'trust as prudence' can hardly be measured separately in empirical analyses. If firms assess their level of trust in a customer (supplier) in a questionnaire, a high level of trust is compatible with both concepts of trust. In both cases, respondents will report a high level of trust because they expect that their vulnerabilities will not be exploited by their partners. Therefore, it is important to ensure that the determinants of inter-firm trust that are investigated empirically in this study do not have opposed effects on 'trust as prudence' and 'trust as hope'; for example a determinant should not have a positive (negative) effect on 'trust as hope' and simultaneously a negative (positive) effect on 'trust as prudence'. Otherwise counteracting effects would make it difficult to interpret the results with respect to the relevance of the determinants of inter-firm trust.

Incoming Knowledge Spillovers: Sako and Helper argue that proprietary knowledge intentionally provided by business partners may create an atmosphere of trust. To see how the disclosure of knowledge by a business partner may be related to inter-firm trust, let us assume that Firm $A$ and Firm $B$ can benefit their trading relationship by exchanging proprietary knowledge concerning their products and production processes or harm the trading partner by behaving opportunistically.

First, it is assumed that unforeseen contingencies exist and that firms deciding on their strategy cannot evaluate all future benefits of their actions. ${ }^{7}$ Nooteboom (2002, p. 5) states that "The machinery of rational choice breaks down when we go beyond risk, in the economist's interpretation as the variance of a distribution of probabilities attached to alternative outcomes." If Firm $A$ still discloses knowledge to Firm $B$, this action may be based on the hope that Firm $B$ acts in a trustworthy manner with the knowledge, that Firm $B$ treats the disclosed knowledge confidentially and does not share

\footnotetext{
7 "An unforseen contingency is a set of circumstances that ex ante the parties to the transaction had not considered" (Kreps 1990, p. 116).
} 
it without permission. Here, 'trust as hope' causes Firm $A$ 's disclosure of knowledge. Consequently, the disclosure of knowledge by Firm $A$ may act as a signal of trust. Furthermore, one might argue that trusting behavior of a firm is an indication of its own trustworthiness. ${ }^{8}$ If Firm $A$ 's signal of trust is indeed perceived by Firm $B$ as a signal of Firm $A$ 's trustworthiness, then Firm $B$ will reciprocate with trust. In other words, the inflow of knowledge from Firm $A$ may be associated with an increase in the level of Firm $B^{\prime} s$ 'trust as hope' in Firm $A .^{9}$ This may lead in turn to a disclosure of knowledge by Firm $B$ to Firm $A$. Thus, the disclosure of knowledge to the other firm is caused by 'trust as hope' and the inflow of knowledge from the other firm causes 'trust as hope'.

Now let us assume a situation similar to the one described in Figure 1 where unforeseen contingencies do not exist and firms can evaluate all future benefits of their actions: Firm $A$ and $B$ participate in a repeated game using standard trigger strategies, and the disclosure of knowledge is the equilibrium of the game. Firm $A$ and Firm $B$ disclose knowledge to each other, because both firms know that they do not have any incentive to exploit each other's vulnerabilities. In this case, both firms receive proprietary knowledge from the other and exhibit a high level of 'trust as prudence' in the other.

Thus, a positive relationship between inflow of knowledge from the partner and trust in the partner is compatible with the concept of 'trust as hope' as well as with the concept of 'trust as prudence'. Moreover, the above discussion suggests that feedback loops may exist (i.e. the level of trust may be

\footnotetext{
${ }^{8}$ Glaeser et al. (2000) and recently Ashraf et al. (2006) report that trustworthiness (measured by the percentage returned in trust experiments) is positively and significantly correlated with attitudinal measures of trust (based on attitudinal survey questions). Of course, this does not necessarily imply that behaviors of trust are good predictors of trustworthiness. To the author's best knowledge empirical studies have yet not dealt with the question of whether behaviors of trust are related to trustworthiness.

${ }^{9}$ It is 'trust as hope' because firm $B$ still does not know whether firm $A$ has an incentive to exploit trust or not.
} 
affected by incoming knowledge spillovers and trust in the relationship may affect the inflow of knowledge from a business partner).

In addition to the voluntary provision of information by a trading partner, an inflow of knowledge may also be the result of a leakage of knowledge not intended by the partner. It is not obvious whether such involuntary spillovers have a positive impact on inter-firm trust, but it can at least be expected that such incoming knowledge spillovers from vertically-related firms do not have a negative impact, irrespective of whether it is 'trust as prudence' or 'trust as hope'. If transfer of knowledge is of any relevance for inter-firm trust, a positive relationship between the inflow of knowledge from a trading partner and the level of trust in the respective business partner is likely.

Hypothesis 1: there is a positive relationship between the inflow of knowledge from customers (suppliers) and suppliers' (customers') trust in customers (suppliers).

Appropriability conditions: A firm can appropriate the returns of its innovations if it is able to protect its proprietary knowledge. Appropriability problems may arise, however, if knowledge leaks out inadvertently to other firms. Potential channels of leakage of knowledge are, for instance, the informal exchange of technical knowledge between employees from different firms, reverse engineering, patent information or movement of employees from one firm to another (Mansfield 1985, p. 221). If the danger of leakage of knowledge is not related to the buyer-supplier relationship, a firm's appropriability problems may not have any impact on trust in customers (suppliers). In this case, it is perfectly possible for a firm to fear that knowledge spills over to competitors and for the same firm to trust its customers (suppliers).

The story might be quite different, however, if the danger of leakage of knowledge $i s$ related to the buyer-supplier relationship. A firm may fear, for instance, that its knowledge will leak out to competitors via common suppliers or customers. For instance, Firm $A$ may disclose a process innovation 
to Firm $B$, and the latter may further transfer disclosed knowledge to Firm $A$ 's competitor. If Firm $A$ cannot protect its process innovation through the complexity of its production process or through lead time in commercialization, such a leakage of knowledge may reduce Firm $A$ 's ability to appropriate the returns of its innovation (see Bönte and Keilbach 2005, Cassiman and Veugelers 2002). Obviously, imperfect appropriability will have a negative impact on a firm's 'trust as prudence' in its suppliers and customers if it creates or increases the business partners' incentive to exploit trust.

How 'trust as hope' is affected by appropriability problems is not that clear. On the one hand, the level of 'trust as hope' is defined as trusting in situations where the partner has an incentive to exploit vulnerabilities. This would imply that 'trust as hope' is not affected by appropriability problems. On the other hand, it does not seem to be very likely that a firm will keep trusting its customers (suppliers), regardless of how severe appropriability problems are. Therefore, it can be expected that, if any, the impact of appropriability problems on firms' level of 'trust as hope' and 'trust as prudence' in customers (suppliers) is negative.

Hypothesis 2: a firm's appropriability problems have a negative impact on the firm's level of trust in customers (suppliers).

Geographical proximity: It is argued by some scholars that 'trust needs touch' (Gallié and Guichard 2005, Handy 1995). In this respect, geographical proximity of trading partners may be associated with a higher level of mutual inter-firm trust in buyer-supplier relationships (Narasimhan and Nair 2005). If geographical proximity reduces the trading partners' incentives to behave opportunistically, the level of 'trust as prudence' in proximate business partners will exceed that of distant ones. Firms may find it easier, for instance, to monitor the actions of geographically proximate trading partners than the actions of distant ones, which would imply that the ability to ascertain whether trading partners behave opportunistically decreases with 
geographical distance. Especially frequent face-to-face contacts, which are facilitated by geographical proximity, may enable trading partners to learn about each others' motives.

Moreover, firms may be embedded in local networks (MacKinnon et al. 2004). If the social and institutional aspects of such networks positively influence 'trust as hope', the level of 'trust as hope' will decrease with distance. Therefore, it can be expected that the potential impact of spatial proximity is positive for both concepts of trust.

Hypothesis 3: Inter-firm trust between business partners located in geographical proximity is higher than inter-firm trust between distant partners.

However, Hypothesis 3 and the other two hypotheses may be interrelated. It is often argued that the transfer of knowledge is easier between proximate firms than between distant ones, and therefore firms are interlinked in local knowledge networks (Audretsch and Feldman 1996, Lawson and Lorenz 1999). Thus, there exists an 'indirect effect' of geographical proximity working via knowledge flows between proximate business partners. Moreover, geographic proximity facilitates the movement of employees from one firm to another (Marshall 1920), and the existence of local labor markets may have an impact on inter-firm trust. On the one hand, employees moving from customers to suppliers and vice versa may contribute to the creation inter-firm trust. On the other hand, 'head-hunting' activities by business partners may have a negative influence on inter-firm trust.

Thus, there may be a 'direct' effect of geographical proximity due to better monitoring and there may exist 'indirect' effects. In the econometric model that will be discussed in Section 4.1, variables are included that capture the effects of labor markets and control for such 'indirect' effects. 


\section{Data}

\subsection{Definition of variables}

Trust in customers and suppliers: Existing empirical studies have tried to identify different types of trust, even though they have not differentiated between 'trust as prudence' and 'trust as hope'. Sako (2000, 1998), for instance, distinguishes between contractual trust and goodwill trust. The former refers to promise keeping irrespective of whether the promises are written or oral, and the latter goes beyond contractual trust, referring to the expectation that the other party is willing to take initiatives over and above what was promised. ${ }^{10}$ According to Sako (2000, p. 89), a precondition of goodwill trust is a consensus on the principle of fairness (i.e. the absence of opportunistic behavior). Sako and Helper have used different scale items to measure different types of trust and opportunism separately. ${ }^{11}$ Similarly, Dyer and Chu (2000) used a trust measure based on the sum of three scale items reflecting fairness and reliability.

In this study, I chose a different approach. First, the dataset on which the empirical analysis is based does not contain different scale items measuring different types of trust. However, the questionnaire gives an explanation of what is meant by 'trust' before asking the question concerning trust. Respondents were provided with the following information about trust: "An atmosphere of trust between business and cooperation partners means, for example, that partners (a) treat the information and the knowledge they share confidentially, (b) do not have to fear to be cheated, (c) do cooperate without detailed legally binding contracts, (d) can rely on each other to make their best effort." This distinction can reflect both 'trust as hope' and

\footnotetext{
${ }^{10}$ See Sako (1998, p. 27).

${ }^{11}$ They found, however, that survey respondents in the USA did not differentiate between different types of trust and opportunism whereas such differences were found for Japanese respondents.
} 
'trust as prudence'. The question used to assess the level of trust in trading partners is "To what degree do you trust your most important business and cooperation partners?" 12

Second, the dataset contains information about levels of trust in spatially proximate and distant trading partners. Respondents could indicate the degree of trust in proximate (distant) customers and proximate (distant) suppliers on a scale from 1 (very low degree of trust) to 6 (very high degree of trust). ${ }^{13}$ Consequently, four different trust measures are used in this study: (1) trust in proximate customers, (2) trust in distant customers, (3) trust in proximate suppliers, (4) trust in distant suppliers. In contrast, Sako and Helper (1998) and Dyer and Chu (2000) exclusively dealt with a supplier's trust in its customers without taking geographical distance into account.

It is assumed here that the trust measures are indicators for the degree of inter-firm trust. This is the case if the general managers who have been interviewed have sufficient knowledge about the trust orientation collectively held by most of the employees towards proximate and distant customers and suppliers. Moreover, the trust measures used in this study may reflect goodwill trust and elements of fairness, such as the absence of opportunism.

Incoming knowledge spillovers: Since quality and quantity of knowledge flows are not observable; an observable indicator that may represent the former is used instead. In the questionnaire, firms were asked for their access to external technical knowledge. Before asking the question, it was

\footnotetext{
${ }^{12}$ Firms that do not have important customers/suppliers in geographic proximity/distance could mark the answer "not existent". The questions are focused on the "most important business partners" in order to reduce ambiguity. In a similar way Sako (2000) has asked automotive suppliers for their most important customer.

${ }^{13} \mathrm{~A}$ very high score indicates that the actual relationship with the trading partner is described adequately by the four aspects (a to d) given in the explanation of inter-firm trust, while a very low score suggests that none of the aspects apply. A medium score may point to the case where some aspects apply and others do not.
} 
explained what was meant by 'access to external technical knowledge': "In order to realize product and process innovations firms may have access to external knowledge of other firms and institutions. This access may be the result of informal exchange of technical knowledge, joint development teams, R\&D contracts, research joint ventures and so on." The corresponding question asked, "How important have been customers (suppliers) in the years from 1997 to 2000 as external sources of knowledge for your innovation activities? Please assess the importance on a scale ranging from 1 ( unimportant) to 6 (very important)." I use the score of this question as a measure of incoming knowledge spillovers.

Imperfect appropriability: Imperfect appropriability was measured by the following question: "How relevant is the danger that technical knowledge generated in your company may 'leak out' to other companies? [Please rate the danger ranging from 1 (no danger) to 6 (great danger)]." The score of this question is my measure of imperfect appropriability. The question does not differentiate between different types of firms (e.g. competitors, customers and suppliers) that may benefit from leakage of knowledge. It does, however, distinguish between proximate and distant firms. Furthermore, it is important that firms assess the danger of leakage of knowledge, as this measure tends to reflect involuntary spillovers that inhibit the firm's ability to appropriate rents from innovations.

Labor sources: Firms were provided with the following information: "Companies need a qualified workforce. Employees may be recruited from universities, colleges or other companies." I measured the relevance of customers (suppliers) as labor sources by the score of the following question. "How important have the following firms and institutions been for your firm's recruiting activities between 1997 and 2000? [Please rate the importance ranging from 1 (irrelevant) to 6 (highly important)]." 
Head-hunting: The danger of head-hunting was measured by the scores of the following question: "How relevant is the danger that your employees are head-hunted by other firms? [Please rate the danger ranging from 1 (no danger) to 6 (great danger)]" Analogous to the measurement of spillovers, this question does not differentiate between different types of firms (e.g. competitors, customers and suppliers). Analogous to the imperfect appropriability measure, this indicator reflects problems of head-hunting due to head-hunting activities of proximate (distant) firms.

Geographical proximity: Theoretical considerations suggest that geographical distance between firms may have an influence on the level of trust as well as on inter-firm knowledge flows. In order to account for the relevance of geography, each of the questions distinguishes between inter-firm linkages to proximate and distant firms. Clear-cut measures of geographical proximity, such as a 50 miles radius, are not used. Instead, the questionnaire allowed the interviewed managers to decide which other firms and institutions are nearby and which ones are distant. In the questionnaire, the firms were provided with different information about the concept of geographic proximity used in this study. First, the notion of geographic proximity was defined by a maximum radius of two hours driving time. Second, it was explained that geographic proximity allows for regular 'face-to-face' contacts. Third, firms were provided with two illustrations in the questionnaire that gave an example of geographic proximity.

\subsection{Descriptive Statistics}

In this study, I use four firm-specific trust measures: trust in proximate/distant customers and trust in proximate/distant suppliers. Therefore, the sample is analyzed along two corresponding dimensions: customers vs. suppliers and proximate vs. distant firms. However, several managers have marked the answer 'not existent' and consequently, these observations can- 
not be used for the further analysis. In addition, several observations had to be dropped due to missing values in the explanatory variables so that we are left with 176 firms and a total number of 637 observations. ${ }^{14}$ Descriptive statistics for this sample are presented in Table 1.

As can be seen from the upper part of the Table 1, the measured level of trust in vertically-related firms is high, ranging from 4.02 to 4.58 . Trust in customers in geographical proximity appears to be higher than trust in other vertically-related firms. In order to check whether these differences are statistically significant, I performed statistical tests. Differences between the mean values of proximate and distant firms are not very large in absolute terms, and the test results indicate that the null hypothesis that they are equal cannot be rejected. In contrast, differences between firms' trust in suppliers and customers exist. The mean values of measured trust in customers are significantly higher than the measured trust in suppliers irrespective where firms are located. Thus, descriptive statistics provide only weak empirical evidence for the hypothesis that geography matters for the emergence of trust. A remarkable difference, however, is found between trust in customers and suppliers.

Similar results are obtained for incoming spillovers. Customers in proximity appear to be more relevant as external knowledge sources than distant customers and suppliers. While differences between proximate and distant firms are statistically insignificant, the differences between customers and suppliers are statistically significant. A somewhat different picture emerges for the relevance of customers and suppliers as labor sources. Here, statistically significant differences between proximate and distant firms exist, whereas results do not indicate that the relevance of customers and suppliers differs. With respect to the measure of imperfect appropriability and the head-hunting measure, I can only test for differences between proximate and

\footnotetext{
${ }^{14}$ The highest possible number of observations is 716 , four observations for each of the 179 firms.
} 
Table 1: Descriptive statistics

\begin{tabular}{|c|c|c|c|}
\hline Trust & proximity & distance & difference \\
\hline customers & 4.58 & 4.38 & $\begin{array}{c}0.20 \\
(1.57)\end{array}$ \\
\hline suppliers & 4.10 & 4.02 & $\begin{array}{c}0.08 \\
(0.57)\end{array}$ \\
\hline difference & $\begin{array}{l}0.48^{* *} \\
(3.79)\end{array}$ & $\begin{array}{l}0.36^{* *} \\
(2.60)\end{array}$ & \\
\hline Knowledge source & proximity & distance & difference \\
\hline customers & 3.42 & 3.39 & $\begin{array}{c}0.03 \\
(0.13)\end{array}$ \\
\hline suppliers & 2.43 & 2.80 & $\begin{array}{c}-0.37 \\
(-1,66)\end{array}$ \\
\hline difference & $\begin{array}{l}0.99^{* *} \\
(4.33)\end{array}$ & $\begin{array}{l}0.59^{* *} \\
(2.65)\end{array}$ & \\
\hline Labor source & proximity & distance & difference \\
\hline customers & 1.90 & 1.48 & $\begin{array}{l}0.42^{* *} \\
(2.93)\end{array}$ \\
\hline suppliers & 1.95 & 1.59 & $\begin{array}{l}0.36^{*} \\
(2.25)\end{array}$ \\
\hline difference & $\begin{array}{l}-0.05 \\
(-0.28) \\
\end{array}$ & $\begin{array}{c}-0.11 \\
(-0.96) \\
\end{array}$ & \\
\hline & proximity & distance & difference \\
\hline Imperf. appropriability & 2.67 & 2.63 & $\begin{array}{c}0.04 \\
(0.84)\end{array}$ \\
\hline Head-hunting & 2.77 & 2.26 & $\begin{array}{c}0.52 \\
\left(2.82^{* *}\right)\end{array}$ \\
\hline
\end{tabular}

Note: Two-sided t-test on differences in two means of dependent (paired) samples. The null hypothesis is that the mean of differences is zero. The asterisks $*$ and ** denote significance at the 5 and 1 percent level, respectively. 
Table 2: Correlations between explanatory variables

\begin{tabular}{lcccc}
\hline \hline Customers & (inc.) spillovers & imp. approp. & labor & head-hunting \\
(inc.) spillovers & 1 & & & \\
imp. approp. & 0.29 & 1 & & \\
labor & 0.18 & 0.08 & 1 & \\
head-hunting & 0.27 & 0.36 & 0.29 & 1 \\
\hline Suppliers & (inc.) spillovers & imp. approp. & labor & head-hunting \\
(inc.) spillovers & 1 & & & \\
imp. approp. & 0.28 & 1 & & \\
labor & 0.10 & 0.18 & 1 & \\
head-hunting & 0.11 & 0.34 & 0.28 & 1 \\
\hline
\end{tabular}

distant firms since these measures reflect problems of appropriability and head-hunting. Test results suggest that, on average, head-hunting by proximate firms is viewed as a greater problem than headhunting activities of distant firms. Such a difference does not exist for the measure of imperfect appropriability.

Table 2 presents the correlation matrix for independent variables separately for customers and suppliers. The strongest correlation can be found between the measure of imperfect appropriability and the head-hunting measure, which may indicate that movement of employees due to other firms' head-hunting activities is one relevant channel for the leakage of knowledge. However, even between these measures the pairwaise correlation is low $(0.34$, 0.36), which suggests that there is no severe multicollinearity problem. 


\section{Empirical Analysis}

\subsection{Econometric Specification}

One way to analyze the data is to compute separate regressions for each trust category. In this case, the estimation equations for each trust category can be specified as follows:

$$
\begin{aligned}
\text { Trust }_{i c p}= & \alpha_{1}+\beta_{11} \text { spill }_{i c p}+\beta_{12} \text { labor }_{i c p}+\beta_{13} \text { iapprop }_{i p} \\
& +\beta_{14} \text { head }_{i p}+\varepsilon_{1 i}, \\
\text { Trust }_{i c d}= & \alpha_{2}+\beta_{21} \text { spill }_{i c d}+\beta_{22} \text { labor }_{i c d}+\beta_{23} \text { iapprop }_{i d} \\
& +\beta_{24} \text { head }_{i d}+\varepsilon_{2 i}, \\
\text { Trust }_{i s p}= & \alpha_{3}+\beta_{31} \text { spill }_{i s p}+\beta_{32} \text { labor }_{i s p}+\beta_{33} \text { iapprop }_{i p} \\
& +\beta_{34} \text { head }_{i p}+\varepsilon_{3 i}, \\
\text { Trust }_{i s d}= & \alpha_{4}+\beta_{41} \text { spill }_{i s d}+\beta_{42} \text { labor }_{i s d}+\beta_{43} \text { iapprop }_{i d} \\
& +\beta_{44} \text { head }_{i d}+\varepsilon_{4 i},
\end{aligned}
$$

where $\varepsilon_{1 i}$ to $\varepsilon_{4 i}$, are error terms, $i(=1, . ., N)$ denotes the firm index, $c p(c d)$ are customers in proximity (distance), $s p(s d)$ are suppliers in proximity (distance), and Trust is the trust measure of each trust category. The variables spill and labor represent the respective measures of the relevance of vertically related firms as knowledge and labor sources. Recall that the iapprop and the head variables, which reflect the danger of leakage of knowledge and the danger of head-hunting, are identical for customer and supplier trust category, but vary with distance $(p, d)$. The $\beta$ parameters reflect the marginal impact of the explanatory variables on trust levels for firms in each category.

Estimating each of the equations separately allows for exploitation of the cross section variation, but not the 'within' firm variation between the trust categories. In order to exploit both the variation 'within' firms as well as the variation 'between' firms, the estimation equation can be specified as follows: 


$$
\begin{aligned}
\text { Trust }_{i t}= & \alpha+\beta_{1} \text { spill }_{i t}+\beta_{2} \text { labor }_{i t}+\beta_{3} \text { iapprop }_{i g}+\beta_{4} \text { head }_{i g} \\
& +\gamma \text { prox }+u_{i t} \\
& \\
& i=1, . ., N ; t=c p, c d, s p, s d ; g=p, d .
\end{aligned}
$$

where the variables Trust, spill and labor have a double subscript, with $i$ denoting the firms and $t$ denoting customers in proximity (distance) and suppliers in proximity (distance). Since the measures of imperfect appropriability (iapprop) and the head-hunting measure (head) do not vary with customer and supplier, they are indexed by $g$ and not by $t$. Furthermore, a proximity-dummy (prox) is included into the regression that takes the value one if the trust measure belongs to the proximity category and zero otherwise. This dummy variable captures all effects of geographical proximity common to all firms that are not controlled for by the 'indirect effects' of the explanatory variables, and I interpret the parameter $\gamma$ as the 'direct' effect of geographical proximity on trust levels.

This econometric specification allows me to take into account unobserved heterogeneity of firms. The disturbance term of the one-way error component model that is used in most panel data applications is specified as follows (Baltagi 1995, p. 9):

$$
u_{i t}=\mu_{i}+v_{i t}, \quad i=1, . ., N ; t=c p, c d, s p, s d,
$$

where $\mu_{i}$ denotes the unobservable firm-specific effect and $v_{i t}\left(\sim I I D\left(0, \sigma^{2}\right)\right)$ is the remainder disturbance. The former controls for firm-specific effects that are not included in the regression, such as omitted variables and misspecifications. The firm-specific effect may reflect, for instance, the collectively-held trust orientation by employees of a firm $i$ towards partner firms in general. Two different assumptions about $\mu_{i}$ are usually made: firm-specific effects 
are assumed to be fixed parameters, or it is assumed that $\mu_{i}$ is randomly distributed across firms with $\mu_{i} \sim I I D\left(0, \sigma^{2}\right) .{ }^{15}$ It is often argued that the fixed effects model is a reasonable approach, if one focuses on a specific sample of $\mathrm{N}$ firms, while the random effects model is appropriate if one is drawing $N$ firms randomly from a large population (Baltagi 1995, Greene 2003).

The properties of firm-specific effects, however, are relevant for the estimation of this model. If firm-specific effects do not exist $\left(\mu_{i}=0\right)$, the simple OLS estimator provides consistent and efficient estimates of the $\beta$ parameters. If fixed effects exist, simple OLS estimates are biased since the explanatory variables are correlated with $u_{i t}$, whereas the fixed effects estimator provides unbiased results. If they are randomly distributed, simple OLS as well as fixed effects estimator provide consistent estimates, but these are not efficient. In this case, a GLS estimator is appropriate. Therefore, I will provide specification tests for the different models in order to identify the appropriate model.

Two objections can be raised against the econometric specification of the estimation equation (2). First, it may be criticized that a linear specification of the relationship between trust and the explanatory variables does not take into account the ordinal nature of the dependent variable. Second, it can be argued that it is not appropriate to assume that the parameters of the four trust equations are identical. Results of an empirical analysis reported in appendix $\mathrm{B}$ show that the linear specification is a reasonable approximation. ${ }^{16}$ Moreover, results suggest that differences between trust in customers and suppliers may exist. Therefore, a dummy-variable that takes the value 1 when trust is measured by trust in customers and zero otherwise is included into the estimation equation (2). This dummy variable captures the differences between trust in customers and trust in suppliers that are not

\footnotetext{
${ }^{15}$ The explanatory variables are assumed to be independent of $\mu_{i}$ and $v_{i t}$.

${ }^{16}$ Appendices are available on the JEBO website. The robustness of estimation results with respect to the choice of estimation method has also been reported by Dyer and Chu (2000) and Sako and Helper (1998).
} 
controlled for by the explanatory variables. Moreover, estimation results of separate regression for customers and suppliers will be presented.

\subsection{Estimation Results}

The estimation results of simple OLS, fixed effects and random effects estimations are reported for an unbalanced and a balanced panel in Tables 3 and 4. The unbalanced panel consists of 176 firms and 637 observations. The balanced panel consists of 133 firms with four observations per firm and thus a total number of 532 observations. The $\mathrm{R}^{2}$ of each regression is relatively low $(\leq .07)$, with the exception of the fixed effects estimation $(.65 ; .67)$. The high explanatory power of the fixed effects estimation implies that trust levels are mainly 'explained' by unobservable firm-specific fixed effects. The results of Hausman specification tests, however, do not reject the null hypothesis that firm-specific effects are random. The estimated coefficient of the customer-dummy variable is positive and statistically significant in all regressions. This indicates that firms' trust in customers exceeds their trust in suppliers, which is in line with the descriptive statistics presented in Section 3.2 .

The estimated coefficient of the incoming spillover variable is positive and statistically significant in the simple OLS, the fixed, and the random effects estimation for the unbalanced and the balanced panel. Thus, Hypothesis 1 has to be accepted. As predicted by Hypothesis 2, the estimated coefficient of the imperfect appropriability variable is negative throughout the regressions. It is statistically significant in simple OLS and random effects while statistically insignificant in the fixed effects regression. In addition, I performed a 'between' estimation, which is simply a regression of the average trust level of each firm on the average values of the explanatory variables. This cross-section estimation provides a positive but statistically insignificant

estimate of the coefficient of the incoming spillover variable and negative and statistically significant coefficient of the imperfect appropriability variable. 
Table 3: Determinants of Trust in Customers and Suppliers (unbalanced panel)

\begin{tabular}{|c|c|c|c|c|}
\hline & Simple OLS & Fixed & Random & Between \\
\hline \multirow{2}{*}{ (Incoming) spillovers } & $0.073^{* *}$ & $0.098^{* *}$ & $0.085^{* *}$ & 0.049 \\
\hline & $(2.86)$ & $(3.57)$ & $(3.52)$ & $(0.97)$ \\
\hline \multirow{2}{*}{ Imperf. appropriability } & $-0.119^{* *}$ & -0.042 & $-0.082^{*}$ & -0.107 \\
\hline & $(-3.31)$ & $(-0.82)$ & $(-2.12)$ & $(-1.74)$ \\
\hline \multirow{2}{*}{ Labor source } & -0.017 & 0.029 & 0.009 & -0.077 \\
\hline & $(-0.43)$ & $(0.68)$ & $(0.25)$ & $(-0.91)$ \\
\hline \multirow{2}{*}{ Head-hunting } & 0.029 & 0.007 & 0.021 & 0.045 \\
\hline & $(0.87)$ & $(0.17)$ & $(0.62)$ & $(0.68)$ \\
\hline \multirow{2}{*}{ Proximity dummy } & 0.159 & $0.197^{* *}$ & $0.179^{* *}$ & \\
\hline & $(1.54)$ & $(2.42)$ & $(2.32)$ & \\
\hline \multirow{2}{*}{ Customer dummy } & $0.375^{* *}$ & $0.311^{* *}$ & $0.332^{* *}$ & 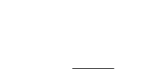 \\
\hline & $(3.83)$ & $(4.33)$ & $(4.72)$ & \\
\hline \multirow{2}{*}{ Constant } & $4.033^{* *}$ & \multirow{2}{*}{-} & $3.899^{* *}$ & $4.429^{* *}$ \\
\hline & $(29.61)$ & & $(26.95)$ & $(18.32)$ \\
\hline$R^{2}$ & 0.06 & 0.67 & 0.05 & 0.02 \\
\hline Standard Error & 1.2096 & 0.8394 & 1.2122 & 1.0117 \\
\hline F-test: Total vs. FE & - & $4.87^{* *}$ & - & - \\
\hline$\chi^{2}$-test: RE vs. FE & - & - & 9.49 & - \\
\hline Observations & 637 & 637 & 637 & 176 \\
\hline
\end{tabular}


Table 4: Determinants of Trust in Customers and Suppliers (balanced panel)

\begin{tabular}{lcccc}
\hline \hline & Simple OLS & Fixed & Random & Between \\
\hline (Incoming) spillovers & $0.079^{* *}$ & $0.100^{* *}$ & $0.091^{* *}$ & 0.067 \\
& $(2.71)$ & $(3.37)$ & $(3.43)$ & $(1.13)$ \\
Imperf. appropriability & $-0.126^{* *}$ & -0.029 & $-0.087^{*}$ & $-0.144^{*}$ \\
& $(-3.31)$ & $(-0.51)$ & $(-2.06)$ & $(-2.23)$ \\
Labor source & 0.0020 & 0.015 & 0.011 & -0.012 \\
& $(0.05)$ & $(0.33)$ & $(0.27)$ & $(-0.12)$ \\
Head-hunting & 0.008 & -0.010 & 0.0016 & 0.012 \\
& $(0.21)$ & $(-0.21)$ & $(0.04)$ & $(0.16)$ \\
Proximity dummy & $0.274^{*}$ & $0.273^{* *}$ & $0.272^{* *}$ & - \\
& $(2.49)$ & $(3.10)$ & $(3.23)$ & \\
Customer dummy & $0.325^{* *}$ & $0.310^{* *}$ & $0.317^{* *}$ & - \\
& $(3.12)$ & $(4.15)$ & $(4.28)$ & \\
Constant & $3.984^{* *}$ & & $3.847^{* *}$ & $4.383^{* *}$ \\
$R^{2}$ & $(27.35)$ & & $(24.34)$ & $(16.36)$ \\
Standard Error & 0.07 & 0.65 & 0.06 & 0.04 \\
F-test: Total vs. FE & 1.1590 & 0.8222 & 1.1611 & 0.9234 \\
$\chi^{2}$-test: RE vs. FE & - & $4.93^{* *}$ & - & - \\
Observations & - & - & 2.73 & - \\
\hline
\end{tabular}

Notes: The t-values are reported in parentheses. The asterisks ${ }^{*}$ and ${ }^{* *}$ denote significant at the 5 and 1 percent level, respectively. 
Differences between the fixed effects and the between estimation results with respect to the significance level of the spillover variable and the imperfect appropriability variable may be intuitively explained by the fact that the former estimator wipes out the firm-specific effects and thus ignores the cross-section variation in the panel, whereas the latter ignores the 'within' variation of the variables. Therefore, the results of the fixed effects regressions suggest that the variation in the four trust scores 'within' each firm can be explained by the variation in the relevance of incoming spillovers from different trading partners 'within' each firm, but not by the variation in the appropriability conditions. The latter finding may be due to the fact that the measure of imperfect appropriability varies with distance, but not with the type of trading partner. Therefore, it can explain the variation in trust in proximate and distant firms, but not differences between customer and supplier trust. The between estimation, which emphasizes the cross-section variation, suggests that differences between the firms' average trust-levels are, at least to some extent, due to differences in the firms' appropriability conditions. The estimation results for the random effects and the simple OLS estimator, which reflect the 'within' as well as the 'between' variation, indicate that both variables have an impact on trust levels. ${ }^{17}$

Furthermore, the estimation results provide empirical evidence in support of Hypothesis 3. The estimated coefficient of the proximity dummy variable is positive and statistically significant for the balanced panel, and the same result is obtained for the unbalanced panel, controlling for unobserved heterogeneity by using fixed and random effects estimators. Thus, results indicate that geographical proximity matters for the emergence of trust in buyer-supplier relations.

The estimated coefficient of the labor source variable as well as the esti-

\footnotetext{
${ }^{17}$ The random effects estimator (GLS) is a matrix weighted average of the fixed effects and the between estimator while the simple OLS estimator gives equal weight to the variation within and between firms. See Baltagi (p. 16).
} 
mated coefficient of the head-hunting variable are statistically insignificant throughout all regressions. Thus, the relevance of customers (suppliers) for a firm's recruiting activities and the danger of head hunting activities by other firms do not influence the level of trust in customers and suppliers.

\subsection{Robustness Checks}

In this section I present estimates based on alternative specifications intended to scrutinize the robustness of the results in Table 4 . Columns (2) to (5) in Table 5 present the results of robustness checks, and column (1) reproduces the result of the random effects estimation in Table 4.

First, one might question whether the panel regressions presented thus far adequately control for a correlation of error terms due to potential interrelation of a firm's trust measures. To take such a correlation into account, Equations (1a), (1b), (1c) and (1d) have been estimated by a Seemingly Unrelated Regression Estimation (SURE) procedure. The estimation results for the balanced panel are reported in Column (2) of Table 5. The residuals of the estimation equations are indeed correlated, but controlling for this correlation hardly affects the results. As before, incoming knowledge and appropriability problems have a statistically significant impact on trust. ${ }^{18}$

Furthermore, one might suspect that some of the results of the panel regression can be explained, at least in part, by the fact that firms in the sample are operating in various industries; the result that trust in customers is higher than trust in suppliers. The majority of firms are suppliers of technologically critical 'flying material', such as suppliers of cabin interior components and systems (e.g. aircraft interior plastic products, safety belts, kitchen, vacuum toilets and so on), suppliers of electrical parts (e.g. mea-

\footnotetext{
${ }^{18}$ Although not reported the constant terms are allowed to vary between equations, and their difference is statistically significant. Their estimated values also confirm the previous results; differences between constant terms suggest that trust in proximate firms and trust in customers are higher.
} 
Table 5: Determinants of Trust in Customers and Suppliers: Alternative Specifications (balanced panel)

\begin{tabular}{lccccc}
\hline \hline & $(1)$ & $(2)$ & $(3)$ & $(4)$ & $(5)$ \\
& Random & SUR & Random & G2SLS ${ }^{b)}$ & G2SLS \\
(Inc.) spillovers & $0.091^{* *}$ & $0.114^{* *}$ & $0.089^{* *}$ & $0.164^{*}$ & 0.155 \\
& $(3.43)$ & $(4.49)$ & $(3.35)$ & $(2.07)$ & $(1.80)$ \\
Imperf. approp. & $-0.087^{*}$ & $-0.104^{* *}$ & $-0.08^{*}$ & $-0.102^{*}$ & $-0.099^{*}$ \\
& $(-2.06)$ & $(-2.47)$ & $(-1.99)$ & $(-2.24)$ & $(-2.06)$ \\
Labor source & 0.011 & 0.039 & 0.05 & -0.000 & -0.001 \\
& $(0.27)$ & $(1.06)$ & $(0.14)$ & $(-0.01)$ & $(-0.32)$ \\
Head-hunting & 0.002 & -0.168 & -0.002 & -0.011 & -0.012 \\
& $(0.04)$ & $(-0.45)$ & $(-0.05)$ & $(-0.28)$ & $(-0.75)$ \\
Prox. dummy & $0.272^{* *}$ & & $0.277^{* *}$ & $0.310^{* *}$ & $0.311^{* *}$ \\
& $(3.23)$ & a) & $(3.29)$ & $(3.32)$ & $(3.29)$ \\
Cust. dummy & $0.317^{* *}$ & & $0.318^{* *}$ & $0.262^{* *}$ & $0.269^{* *}$ \\
& $(4.28)$ & a) & $(4.30)$ & $(2.81)$ & $(2.79)$ \\
\hline Industry effects & No & No & Yes & No & Yes
\end{tabular}

NOTES: The t-values are reported in parentheses. The asterisks * and ${ }^{* *}$ denote significant at the 5 and 1 percent level, respectively. a) constant terms are allowed to differ between the equations of the four trust categories. b) G2SLS random-effects instrumental variable regression (Balestra and Varadharajan-Krishnakumar, 1987). 
surement instruments), suppliers of metal products (e.g. aluminum) or engineering firms doing R\&D on cabin systems. Firms were asked to report their official industry code and/or their most important product or group of products. This information was used for the repartition of firms in 8 sectors. Approximately $14 \%$ of the firms are aircraft and spacecraft manufacturers; $14 \%$ manufacturers of electrical parts and other technical products; $17 \%$ manufacturers of basic and fabricated metal products; $13 \%$ manufacturers of chemicals, rubber, and plastic products; and 11\% manufacturers of machinery and equipment. Moreover, $11 \%$ of the firms are wholesalers or retailers, and $17 \%$ are service providers (e.g. software companies, engineering firms and transport services). Industry dummy variables are included in the random effects estimation in order to control for industry-specific effects. The results reported in Column (3) of Table 5 suggest that the values of the estimated coefficients are not substantially affected. Moreover, the industry effects are jointly insignificant. ${ }^{19}$

The first hypothesis in section 2 postulates a positive relationship between trust and the inflow of knowledge; incoming knowledge may positively affect inter-firm trust, and trust in the relationship may affect the inflow of knowledge. If such feedback loops existed, this would imply endogeneity of the incoming knowledge variable. The panel regression presented above, however, is based on the implicit assumption that the variable 'incoming knowledge spillovers' is exogenous with respect to trust in customers (suppliers). Thus, I cannot rule out the possibility that estimation results are biased. To take potential endogeneity of this variable into account, I have employed a two-stage least-squares random-effects estimator, where the measure of incoming knowledge spillovers is regressed on a number of instruments

\footnotetext{
${ }^{19} \mathrm{~A}$ Wald test shows that the industry effects are not statistically significant at a $5 \%$ significance level: $\chi^{2}(7)=11.43$. Although not reported here, interacting the customer dummy with the industry dummies (allowing for industry-specific customer dummies) also leads to statistically insignificant effects.
} 
variables in the first stage. ${ }^{20}$ The results are reported in Columns (4) and (5) of Table 5. The estimated coefficient of the incoming knowledge variable is now higher and statistically significant. Only after inclusion of industryspecific effects does the significance level decrease, but the industry effects are not statistically significant. ${ }^{21}$

Furthermore, I have investigated potential differences between trust in customers and trust in suppliers by performing separate estimations. The results are reported in Tables 6 and 7 . The estimated coefficient of the incoming spillover variable is still positive and statistically significant in the fixed effects and the random effects regressions. Note that now the 'within' variation reflects the changes between proximate and distant firms. Thus, results imply that the variation in the relevance of proximate and distant customers (suppliers) as knowledge sources explains variation in firms' trust in proximate and distant customers (suppliers). Again, results suggest that geographical proximity has a positive impact on trust in customer and trust in suppliers.

There is some evidence, however, that results differ with respect to the impact of appropriability conditions. The sign of the coefficient of the imperfect appropriability variable is still negative in all regressions, but it is only statistically significant in the customer regressions (random effects and between estimation) while statistically insignificant in all supplier regressions. In particular, the results of the between regressions differ remarkably. The

\footnotetext{
${ }^{20}$ The instrument variables are all variables except the knowledge variable. Moreover, for each knowledge source category, the other knowledge source categories have been used as instruments: for instance, the knowledge inflow from distant customers, near suppliers and distant suppliers are instruments for the knowledge inflow from near customers. Furthermore, the squared values of the variables as well as industry-specific dummies and firm size dummies are used as instruments. The estimation results of the first stage are available from the author upon request.

${ }^{21} \mathrm{~A}$ Wald test shows that the industry effects are not statistically significant at a $5 \%$ significance level: $\chi^{2}(7)=11.05$.
} 
estimated coefficient of the spillover variable is -0.198 and statistically significant at the $1 \%$ level in the customer regression whereas its absolute value is lower (-0.08) and statistically insignificant in the supplier regression.

\subsection{Discussion}

The results of the empirical analysis suggest that incoming knowledge spillovers from customers positively affect supplier trust. This confirms the finding reported by Sako and Helper (1998) and Sako (1998) who found that information flows from customers to suppliers have a positive impact on supplier trust. This is remarkable, as these studies exclusively dealt with trust of automotive suppliers in their customers whereas the sample used in this study comprises firms from different industrial sectors.

In contrast to the existing literature (e.g. Sako and Helper 2000, Dyer and Chu 2003), this study not only focuses on suppliers' trust in customers, but the surveyed firms have also rated the degree of trust in their suppliers. Results also indicate a positive and statistically significant impact of incoming knowledge spillovers from suppliers on trust in suppliers. Thus, the level of trust in vertically related firms tends to be higher when trading partners have been important sources of external knowledge in the past irrespective of whether partners are suppliers or customers. Since firms assess the relevance of customers as knowledge sources significantly higher than the relevance of suppliers, this can explain to some extent why trust in customers is significantly higher than trust in suppliers. However, the estimation results also indicate that there is still a positive and statistically significant difference between trust in customers and trust in suppliers that cannot be explained by incoming knowledge spillovers.

Estimation results suggest that firms' appropriability problems have a negative impact on inter-firm trust. At first glance, this finding may seem to be similar to the results of Sako and Helper (1998) and Sako (2000), who found that suppliers' trust in customers decreases if suppliers provide infor- 
Table 6: Determinants of Trust in Customers (balanced panel)

\begin{tabular}{lccc}
\hline \hline & Fixed & Random & Between \\
\hline (Incoming) spillovers & $0.142^{* *}$ & $0.087^{*}$ & 0.023 \\
& $(2.71)$ & $(2.23)$ & $(0.40)$ \\
Imperf. appropriability & -0.020 & $-0.103^{*}$ & $-0.198^{* *}$ \\
& $(-0.31)$ & $(-2.12)$ & $(-2.71)$ \\
Labor source & $0.127^{*}$ & 0.090 & -0.003 \\
& $(1.73)$ & $(1.57)$ & $(-0.04)$ \\
Head-hunting & -0.070 & -0.019 & 0.069 \\
& $(-1.37)$ & $(-0.43)$ & $(0.79)$ \\
Proximity dummy & $0.271^{* *}$ & $0.239^{* *}$ & - \\
& $(2.64)$ & $(2.47)$ & \\
Constant & - & $4.161^{* *}$ & $4.676^{* *}$ \\
$R^{2}$ & $(22.04)$ & $(15.49)$ \\
Standard Error & 0.85 & 0.04 & 0.06 \\
F-test: OLS vs. FE & 5.6547 & 1.1681 & 1.0590 \\
Hausman-test & - & - & - \\
Observations & 266 & 266 & - \\
\hline Notes: The t-values are reported in parentheses. The asterisks * and & & \\
at the 5 and 1 percent level, respectively. & &
\end{tabular}


Table 7: Determinants of Trust in Suppliers (balanced panel)

\begin{tabular}{|c|c|c|c|}
\hline & Fixed & Random & Between \\
\hline \multirow{2}{*}{ (Incoming) spillovers } & $0.188^{* *}$ & $0.131^{* *}$ & 0.099 \\
\hline & $(3.10)$ & $(3.30)$ & $(1.84)$ \\
\hline \multirow{2}{*}{ Imperf. appropriability } & -0.064 & -0.078 & -0.080 \\
\hline & $(-0.84)$ & $(-1.50)$ & $(-1.13)$ \\
\hline \multirow{2}{*}{ Labor source } & 0.058 & -0.004 & -0.063 \\
\hline & $(0.66)$ & $(-0.07)$ & $(-0.72)$ \\
\hline \multirow{2}{*}{ Head-hunting } & 0.007 & 0.002 & -0.032 \\
\hline & $(0.12)$ & $(0.15)$ & $(-0.39)$ \\
\hline Proximity dummy & $\begin{array}{c}0.307^{*} \\
(2.61)\end{array}$ & $\begin{array}{c}0.318^{* *} \\
(2.88)\end{array}$ & - \\
\hline \multirow{2}{*}{ Constant } & & $3.712^{* *}$ & $4.170^{* *}$ \\
\hline & & $(18.87)$ & $(14.67)$ \\
\hline$R^{2}$ & 0.79 & 0.04 & 0.03 \\
\hline Standard Error & 0.7675 & 1.1637 & 1.0313 \\
\hline F-test: OLS vs. FE & $3.54^{* *}$ & - & - \\
\hline Hausman-test & - & $\chi^{2}(4)=3.42$ & - \\
\hline Observations & 266 & 266 & 133 \\
\hline
\end{tabular}


mation to customers without reciprocation. There is, however, an important difference between this study and the above mentioned studies. In this study, a measure is used that reflects involuntary information sharing, since firms evaluate the danger of leakage of technical knowledge to other firms in general. In contrast, the measure used by Sako and Helper (1998) and Sako (2000) reflects the difference between the voluntary provision of information by customers and the voluntary provision of information by suppliers. Hence, the measure used in this study captures a firm's appropriability problems in general while their measure reflects asymmetries in the exchange of information (a lack of reciprocity). The negative impact of appropriability problems on a firm's trust in customers (suppliers) found in this study is likely to reflect a decrease in 'trust as prudence' due to appropriability problems, but it cannot be ruled out that 'trust as hope' also decreases.

Furthermore, the estimation results provide empirical evidence supporting the hypothesis that geographical proximity between business partners has a positive effect on inter-firm trust. The statistically significant coefficient of geographical proximity dummy is remarkable because the measure of trust used in this study might be biased against this result. The trust questions asked focus on the 'most important business partners'. However, firms may trust their most important trading partners irrespective where the partner is located because they have many and repeated transactions. This may lead to an underestimation of the effect of geographical distance, therefore further emphasizing the relevance of geographical proximity for the emergence of trust.

These results may have implications for firms' cooperative behavior. If trust were viewed as a tendency to cooperate, the negative impact of appropriability problems would imply that firms that exhibit a low level of trust in business partners due to appropriability problems may have a lower propensity to cooperate. This interpretation is supported by the results of recent empirical studies on R\&D cooperation between customers and suppliers. 
Bönte and Keilbach (2005) and Cassiman and Veugelers (2002) report that the probability of cooperating for innovation is indeed negatively affected by imperfect appropriability. Furthermore, a higher level of trust between geographically proximate partners may facilitate establishing and maintaining cooperative relationships between these partners.

Several empirical studies have found a positive impact of trust on economic success. This may be explained by its relevance for cooperative relationships that may avoid inefficiencies due to noncooperative behavior (Gambetta 1988, Zak and Knack 2001). As pointed out in Section 2, inter-firm trust may be 'trust as prudence' or 'trust as hope'. The former pertains to cooperations in an ideal (economic) world with perfect information where complete contracts can fully specify the action of each agent in every contingency. 'Trust as hope' may therefore help to overcome non-cooperative behavior in environments characterized informational incompleteness. Sako (1998, p. 26) states that "Trust is important and useful, particularly in facilitating cooperation in uncertain environments and unforeseen circumstances". 22

One shortcoming of the empirical analysis is surely the lack of an indicator for the degree of contractural completeness. If contracts between customers and suppliers are sufficiently complete (i.e. contracts specify each party's duties, and contracts can be enforced), there are no vulnerabilities to be exploited. The direct consequence of complete contracts would be a very high level of trust in customers (suppliers) reported by sample firms. The degree of contractural completeness may depend on the type of contract, on firm characteristics, and on industry characteristics. In the present study, it is not possible to control for the completeness of certain contracts since trust questions in the questionnaire are not related to specific contractural

\footnotetext{
${ }^{22}$ It is fair to say that cooperations that are facilitated by trust can also be total welfare reducing; for example trust may facilitate collusion between firms at the expense of consumers.
} 
agreements. Instead, the sample firms assessed the general level of trust in their most important customers (suppliers). However, to the extent to which contractural completeness is firm-specific and/or industry-specific, it has been controlled for by taking into account firm and industry-specific effects in the econometric specification. The results presented above suggest that taking into account such effects hardly affects the estimation results.

In additon, empirical results suggest that trust in customers is higher on average than trust in suppliers. Can this result be explained by the perception that the level of 'trust as prudence' in customers is higher? One could argue, for instance, that firms may know that contracts discipline 'untrustworthy' behavior of customers more effectively than 'untrustworthy' behavior of suppliers. In this case, a higher degree of contractual completeness would imply a higher level of 'trust as prudence' in customers. Moreover, one could argue that the level of 'trust as prudence' is positively related to relationshipspecific investments. A firm may only be willing to make such an investment if the trading partner does not have any incentive to take advantage of the vulnerabilities created by such an investment; for example the partner will not hold up the firm after investment is made. If relationship-specific investments have to be made by suppliers rather than by customers, this may explain a higher level of 'trust as prudence' in customers. Alternatively, the significant difference might be explained by differences in 'trust as hope'. Firms might "hope", for instance, that they stay in good relations with their most important customer so that the latter does not switch to other suppliers and this may lead to observed higher measures of trust. The results presented by MacKinnon et al. point to this direction. Based on interview data of small and medium sized firms in the Aberdeen Oil complex, MacKinnon et al. (p. 100) report that "trust was seen as particularly important in terms of the need to remain flexible and responsive to customers' enquiries and demands" and that "the expectations of both customers and suppliers are crucially supported and sustained through social relationships between 
key individuals".

\section{Conclusion}

This study examines the impact of knowledge spillovers and geographical proximity on inter-firm trust in buyer-supplier relations. Empirical findings suggest that incoming spillovers, imperfect appropriability, and geographic proximity have an impact on firm' trust in customer and suppliers. In particular, this study provides the following three findings:

First, the results of the empirical analysis suggest that incoming knowledge spillovers from customers (suppliers) are positively related to firms' trust in customers (suppliers). The level of trust in vertically related firms is higher when trading partners have been an important source of knowledge in the past. Second, results provide empirical evidence for the relevance of appropriability conditions for inter-firm trust between customers and suppliers. The greater the danger of leakage of technical knowledge to other firms, the lower is the suppliers (customers) level of trust in customers (suppliers). This result implies that the emergence of trust is hampered when firms are not able to protect their proprietary innovations. Third, the estimation results support the notion that geographical proximity has a positive impact on inter-firm trust. Inter-firm trust between geographically close business partners is significantly higher than inter-firm trust between distant firms. Moreover, results suggest that inter-trust in customers exceeds inter-trust in suppliers even if one controls for the effects of the above mentioned determinants.

\section{Acknowledgements}

I am grateful for very helpful comments by Adam Lederer, Erik Monsen, Björn Möller, Wilhelm Pfähler, Isabell Guillen Pinto, Lars Wiethaus and three anonymous referees. Previous versions of this paper were written while 
I was a researcher at the University of Hamburg and the RWI Essen. 


\section{References}

Ashraf, N., Bohnet, I., Piankov, N., 2006. Decomposing trust and trustworthiness. Experimental Economics 9, 193-208.

Audretsch, D., Feldman, M., 1996. Knowledge spillovers and the geography of innovation and production. American Economic Review 86, 630-640.

Balestra, P., Varadharajan-Krishnakumar, J., 1987. Full-information estimations of a system of simultaneous equations with error component structure. Econometric Theory 3, 223-246.

Baltagi, B. H., 1995. Econometric Analysis of Panel Data. New York: Wiley. Bönte, W., Keilbach, M., 2005. Concubinage or marriage? informal and formal cooperation for innovation. International Journal of Industrial Organization 23, 279-302.

Cassiman, B., Veugelers, R., 2002. R\&D cooperation and spillovers: some empirical evidence from Belgium. American Economic Review 92, 1169-1184.

Craswell, R., 1993. On the uses of trust: comment on Williamson, calculativeness, trust, and economic organization. Journal of Law and Economics $36,487-500$.

Dyer, J.H., Chu, W., 2000. The determinants of inter-firm trust in supplierautomaker relationships in the U.S., Japan and Korea. Journal of International Business Studies 31, 259-285.

Dyer, J.H., Chu, W., 2003. The role of trustworthiness in reducing transaction costs and improving performance: empirical evidence from the United States, Japan and Korea. Organization Science 14, 57-68.

Fisman, R., Khanna, T., 1999. Is trust a historical residue? information flows and trust levels. Journal of Economic Behavior and Organization 38, 79-92. 
Gambetta, D., 1988. Can we trust in trust? In: Gambetta, D. (Ed.), Trust: Makin' and Breakin' cooperative Relations. New York: Blackwell, 213-237.

Gallié, E.P., Guichard, R., 2005. Do collaboratories mean the end of faceto-face internteractions? an evidence from the ISEE project. Economics of Innovation and New Technology 14, 517-532.

Glaeser, E.L., Laibson, D.I., Scheinkman, J., Souter, C.L., 2000. Measuring trust. Quarterly Journal of Economics 115, 811-846.

Greene, W.H., 2003. Econometric Analysis, 5th Edition. New York: Prentice Hall.

Handy, C., 1995. Trust and the virtual organization. Harvard Business Review 73, 40-50.

James Jr., H.S., 2002. The trust paradox: a survey of economic inquiries into the nature of trust and trustworthiness. Journal of Economic Behavior and Organization 47, 291-307.

Knack, S., Keefer, P., 1997. Does social capital have an economic payoff? a cross-country investigation. Quarterly Journal of Economics 112, 1251-1288. Kreps, D.M., 1990. Corporate culture and economic theory. In: Alt, J.E., Shepsle, K.A. (Eds.), Perspectives on Positive Political Economy. New York: Cambridge University Press, 90-143.

Lane, C., Bachmann, R., 1996. The social constitution of trust: supplier relations in Britain and Germany. Organization Studies 17, 365-395.

La Porta, R., Lopez-de-Silanes, F., Shleifer, A., Vishny, R., 1997. Trust in large organizations. American Economic Review 87, 333-338.

Lawson, C., Lorenz, E., 1999. Collective learning, tacit knowledge and regional innovative capacity. Regional Studies 33, 305-317.

MacKinnon, D.,Chapman, K., Cumbers, A., 2004. Networking, trust and embeddedness amongst SME's in the Aberdeen oil complex. Entrepreneurship and Regional Development 16, 87-106. 
Mansfield, E., 1985. How rapidly does new industrial technology leak out? Journal of Industrial Economics 34, 217-223.

Marshall, A., 1920, Principles of Economics. London: Macmillan.

Narasimhan, R., Nair, A., 2005. The accedent role of quality, information sharing and supply chain proximity on strategic alliance formation and performance. International Journal of Production Economics 96, 301-313.

Nooteboom, B., 2002. Trust Forms, Foundations, Functions, Failures and Figures. Cheltenham, UK; Northampton, MA, USA: Edward Elgar.

Pfähler, W., Lublinski, A. E., 2003. Luftfahrt-Cluster Hamburg Norddeutschland - Bestandsaufnahme, Perspektiven und Vision für die Zulieferindustrie. Frankfurt/Main: Peter Lang Verlag.

Sako, M., Helper, S., 1998. Determinants of trust in supplier relations: evidence from the automotive industry in Japan and the United States. Journal of Economic Behavior and Organization 34, 387-417.

Sako, M., 1998. The informational requirements of trust in supplier relations: evidence from Japan, Europe and the United States. In: Lazaric, N., Lorenz, E. (Eds.). Trust and Economic Learning. Cheltenham: Edward Elgar, 23-47.

Sako, M., 2000. Does trust improve business performance? In: Lane, C., Backmann, R. (Eds.). Trust Within and Between Organizations. Oxford: Oxford University Press, 88-117.

Schwab, K., Malleret, T., 2003. The trust deficit. The Wall Street Journal Europe, January 28, A 10.

Zaheer, A., McEvily, B., Perrone, V., 1998. Does trust matter? exploring the effects of interoganizational and interpersonal trust on performance. Organization Science 9, 141-159.

Zak, P.J., Knack, S., 2001. Trust and growth. Economic Journal 111, 295321 . 


\section{A Data source}

The data used in this study are drawn from a survey of German aeronautical firms conducted in June 2001. ${ }^{23}$ A sample of 514 aeronautical firms from Germany has been surveyed. These firms have in common an aeronautical affinity due to the fact that they are linked to aeronautic firms in networks, such as input-output networks, knowledge networks, labor networks, and so on. They are either officially assigned to the aeronautical sector themselves, suppliers of technologically critical inputs to aeronautic firms, members of aeronautic business associations or R\&D cooperation partners to aeronautic firms. The sample has been drawn from the following data-bases: Airbus Deutschland GmbH, Hamburg (list of suppliers' of technologically critical "flying material"), Airbus Deutschland GmbH, Hamburg (list of R\&D cooperation partners), Hanse Aerospace e.V., Hamburg (list of the Northern German aeronautics business association members), Bundesverband der Deutschen Luft- und Raumfahrtindustrie e.V., Berlin (list of the German aeronautics business association members), chambers of commerce (list of aeronautical firms). The firms have been contacted by telephone and email in order to arrange a telephone interview with its general managers. Interviews were conducted in June 2001 on the basis of a detailed questionnaire. The final questionnaire was developed following two types of pilot studies. Pre-tests were run both face-to-face as well as by telephone. In total 179 firms have been willing to give an interview, which corresponds to a response rate of $34.8 \%$.

\footnotetext{
${ }^{23}$ The survey has been originally designed to collect data on agglomeration forces. See Pfähler and Lublinski (2003) for further details.
} 


\section{B Estimation Results}

In order to check whether the linear specification is a reasonable approximation the relationship between trust and the explanatory variables has been estimated by using a simple OLS estimator as well as by using an ordered probit model that is appropriate for ordered data (Greene 2003, pp. 736). As can be seen from Tables 8 and 9 similar results with respect to sign and significance levels of the estimated coefficients are obtained. Thus, the linear specification is a reasonable approximation. ${ }^{24}$

The equations (1a - 1d) have been estimated separately (see Table 9) and tests for poolability of the data have been performed. The results suggest that no difference between proximate and distant customers (suppliers) exist while the null hypothesis of poolability of customer and supplier data is rejected (see Table 10$)$.

\footnotetext{
${ }^{24}$ Note, that the estimated coefficients of the OLS regression represent the marginal effects of the respective variables although this interpretation is not strictly correct for the estimated coefficients of the ordered probit model. However, the sign of a coefficient has a clear interpretation for the extreme cases 'very low degree of trust' and 'very high degree of trust'. A negative (positive) coefficient implies, for instance, that the increase in the respective variable leads to a decrease (increase) in a firm's probability of having a high degree of trust. See Greene (p. 738).
} 
Table 8: Ordered Probit Estimation of the Determinants of Trust

\begin{tabular}{ccccc}
\hline \hline & $\begin{array}{c}\text { Customer } \\
\text { (proximity) }\end{array}$ & $\begin{array}{c}\text { Customer } \\
\text { (distance) }\end{array}$ & $\begin{array}{c}\text { Supplier } \\
\text { (proximity) }\end{array}$ & $\begin{array}{c}\text { Supplier } \\
\text { (distance) }\end{array}$ \\
\hline (Incoming) spillovers & 0.028 & 0.046 & $0.116^{*}$ & 0.038 \\
Imperf. appropriability & $(0.62)$ & $(1.05)$ & $(2.49)$ & $(0.89)$ \\
Labor source & $-0.132^{*}$ & $-0.123^{*}$ & -0.032 & $-0.123^{*}$ \\
Head-hunting & -0.005 & $(-2.07)$ & $(-0.56)$ & $(-2.13)$ \\
Constant & $(-0.09)$ & $(0.07)$ & $(-0.83)$ & -0.08 \\
Scaled R & 0.063 & 0.079 & -0.039 & 0.044 \\
Log-Likelihood & $(1.09)$ & $(1.23)$ & $(-0.64)$ & $(0.70)$ \\
LR-test (zero slopes) & $2.09^{* *}$ & $1.88^{* *}$ & $1.939^{* *}$ & $2.22^{* *}$ \\
Observations & $(6.87)$ & $(6.34)$ & $(6.72)$ & $(7.07)$ \\
\hline Not & 0.03 & 0.03 & 0.05 & 0.03 \\
\hline
\end{tabular}

Notes: The t-values are reported in parentheses. The asterisks ${ }^{*}$ and ${ }^{* *}$ denote significant at the 5 and 1 percent level, respectively. 
Table 9: Trust category-specific OLS regressions: Determinants of Trust for Customer and Suppliers

\begin{tabular}{ccccc}
\hline \hline & $\begin{array}{c}\text { Customer } \\
\text { (proximity) }\end{array}$ & $\begin{array}{c}\text { Customer } \\
\text { (distance) }\end{array}$ & $\begin{array}{c}\text { Supplier } \\
\text { (proximity) }\end{array}$ & $\begin{array}{c}\text { Supplier } \\
\text { (distance) }\end{array}$ \\
\hline (Incoming) spillovers & 0.043 & 0.057 & $0.141^{*}$ & 0.051 \\
Imperf. appropriability & $(0.89)$ & $(1.09)$ & $(2.61)$ & $(0.99)$ \\
Labor source & $(-2.36)$ & $(-1.99)$ & $(-0.43)$ & $(-2.09)$ \\
Head-hunting & -0.002 & 0.013 & -0.060 & -0.08 \\
Constant & $(-0.03)$ & $(0.13)$ & $(-0.78)$ & $(-0.08)$ \\
& 0.054 & 0.071 & -0.046 & 0.041 \\
$R^{2}$ & $(0.89)$ & $(0.94)$ & $(-0.66)$ & $(0.56)$ \\
Standard Error & $4.65^{* *}$ & $4.36^{* *}$ & $4.092^{* *}$ & $4.16^{* *}$ \\
Observations & $(19.13)$ & $(15.59)$ & $(15.23)$ & $(15.07)$ \\
& 0.03 & 0.03 & 0.05 & 0.03 \\
\hline
\end{tabular}

Notes: The t-values are reported in parentheses. The asterisks ${ }^{*}$ and ${ }^{* *}$ denote significant at the 5 and 1 percent level, respectively.

Table 10: Results of Chow tests for Poolability of the Data

\begin{tabular}{cc}
\hline \hline Null Hypothesis & Test Statistic \\
\hline Coefficients of proximate and distant customers are equal & $F(2,326)=0.789$ \\
Coefficients of proximate and distant suppliers are equal & $F(2,301)=2.538$ \\
Coefficients of customers and suppliers are equal & $F(2,632)=8.77^{* *}$ \\
\hline \multicolumn{2}{c}{ Notes: The t-values are reported in parentheses. The asterisks ${ }^{*}$ and ${ }^{* *}$ denote } \\
significant at the 5 and 1 percent level respectively.
\end{tabular}




\begin{tabular}{lll|c|}
\multicolumn{3}{c}{ Customer } \\
& & Trust & No Trust \\
\cline { 3 - 4 } Supplier & \multirow{2}{*}{$\begin{array}{l}\text { Trust } \\
\text { No Trust }\end{array}$} & $a, a$ & $-d, a+c$ \\
\cline { 3 - 4 } & & $a+c,-d$ & 0,0 \\
\cline { 3 - 4 } & & &
\end{tabular}

Fig. 1. Trust Game 